\title{
MicroRNAs Play Significant Roles in Pathogenesis of HBV-Related Diseases
}

\author{
Gaoyun Chen', Min Liu'1, Zhigang Jiang1, Mengbin Yu1, Sichen Wei ${ }^{2}$ \\ ${ }^{1}$ Institute of Chemical Defense, Beijing, China \\ ${ }^{2}$ Faculty of Science of Beijing University of Chemical Technology, Beijing, China \\ Email: chengaoyun82@163.com,1260971848@qq.com
}

How to cite this paper: Chen, G.Y., Liu, M., Jiang, Z.G., Yu, M.B. and Wei, S.C. (2016) MicroRNAs Play Significant Roles in Pathogenesis of HBV-Related Diseases. J. Biomedical Science and Engineering, 9, 78-89. http://dx.doi.org/10.4236/jbise.2016.910B011

Received: June 27, 2016

Accepted: September 20, 2016

Published: September 23, 2016

\begin{abstract}
MicroRNAs (miRNAs) comprise an important class of small (about $22 \mathrm{nt}$ ) conserved nonprotein-coding RNAs that specifically regulate cellular gene expression at the post-transcriptional level. Increasing researches showed that miRNAs have emerged as critical regulators involved in diverse physiological and pathological processes, including such as proliferation, differentiation and development, apoptosis and pathogen-host interactions. This review summarizes the crucial roles of miRNAs in replication of the Hepatitis B virus (HBV) and the mechanism underlying dysregulation of miRNAs in $\mathrm{HBV}$-associated diseases. MiRNAs are emerged as essential regulators of HBV replication and pathogenesis. To a certain extent, miRNA is a new promising biomarker and useful strategy for diagnosis of HBV-related diseases.
\end{abstract}

\section{Keywords}

MicroRNA, HBV, Expression, Regulation, Biomarker

\section{Introduction}

MicroRNAs (miRNAs) are an abundant class of small (about $18 \sim 25 \mathrm{nt}$ ) conserved non-coding RNA molecules that specifically regulate cellular gene expression at the post-transcriptional level [1]-[3]. MiRNAs are processed from the short imperfect stem-loop precursors which can be encoded in genomes of plants, animals and viruses. Until now, it is believed that miRNA be firstly transcribed as long primary miRNA, which is processed into $60 \sim 80 \mathrm{nt}$ miRNA precursor (pre-miRNA) by cellular RNases III Drosha [1] [4] [5]. Subsequently, the pre-miRNAs are transported from nucleus to cytoplasm by Exportin- 5 and finally cleaved into 22 nt duplexes [1] [6]-[8], which are the mature miRNAs. 
The miRNA first discovered was the Caenorhabditis elegans heterochronic gene lin-4, which inhibits translation by pairing with partially homologous sequences lin-14 in the 3'-untranslated region (UTR) [1] [4] [5] [9]. Up to now, thousands of miRNAs have been identified in animals, plants and virus and their corresponding targets have been reported in kinds of species [10]-[19]. A large number of studies have revealed there are more than 700 different human miRNAs [20] [21], which have been estimated to control $20 \%$ - $30 \%$ of human genes. Extensive reports have demonstrated the importance of miRNA-mediated regulation in the key processes, such as proliferation, differentiation and development, apoptosis, cellular identity and pathogen-host interactions [22]-[26].

However, the mechanism that miRNA regulates gene expression is not completely elucidated, and only in a few examples (lin-4 and let-7 in Caenorhabditis elegans, bantam and mir-14 in fly, and microRNA-23 in human) the relevant biological function of miRNAs has been illuminated [10]. According to the prevalent understanding, the base 2 - 8 of the 5 ' end of the miRNA, which is named as seed sequence, can be perfectly complemented with the 3'UTR of target mRNA [1]. Currently, more and more evidences indicated that miRNAs can take significant part in virus infection. It has been shown that miR-122 is critical for hepatitis C virus (HCV) infection [27] [28]. Similarly, miRNA acts an essential role in replication of the Hepatitis B virus (HBV), and pathogenesis of HBV-related diseases. The expression profile of microRNAs in liver cells can be changed under HBV infection. To a certain extent, miRNA is being the potential biomarker for disease diagnosis [29].

The Hepatitis B virus was discovered in 1966, but even after 50 years, it is still a major global public health problem [30], especially in Asian and African countries. Approximately 350 - 400 million people are affected with $\mathrm{HBV}$ in the world, and up to 1 million suffer from are HBV-related complications every year, including viral hepatitis and hepatocellular carcinoma (HCC) [31]. HBV virions are $\sim 42 \mathrm{~nm}$ double-shell particles. The genome contains four open reading frames (ORF) (S, C, P and X) which encode four major proteins (HBsAg, $\mathrm{HBcAg}$, DN polymase and protein) respectively. After $\mathrm{HBV}$ infects the liver cells, the closed circular DNA (cccDNA) in the nucleus is formed. This cccDNA, as the transcriptional template, is translated by RNA polymase to generate four major RNA transcripts (3.5 nt, $2.4 \mathrm{nt}, 2.1 \mathrm{nt}, 0.7 \mathrm{nt}$ ), the protein transcripted are processed in the ribosomal and Golgi and finally exported from the cell as full virons by vesicular transport [32]-[35].

\section{HBV Modulate Host-Related MiRNA Expression}

After HBV infection, the host-related miRNAs expression can be changed, creating the conditions for further chronic persistent infection. Research showed that HBV could down-regulate miR-101-3p expression by inhibiting its promoter activity, which caused the up-regulation of Rap1b. While, overexpression of miR-101-3p inhibited these processes. Furthermore, the overexpression of Rap1b was able to reverse the suppressed cell proliferation and migration mediated by miR-101-3p [36]. 
The $\mathrm{X}$ protein $(\mathrm{HBx})$ encoded by $\mathrm{HBV}$ gene, which relative molecular mass is about $1.7 \times 104$, is a multifunctional protein and plays an crucial role in the process of changing host-related miRNAs expression. HBx has trans-activation of cellular and vial genes, which has been implicated in mediating multiple viral and cellular events in $\mathrm{HBV}$-infected cells, including viral replication, transactivation of transcription factors, signal transduction, cell-cycle progression, and cell death [37]-[39]. In addition, HBx protein has been implicated in the development of hepatocellular carcinoma by interfering with normal cellular processes. MiR-101 expression was down-regulated through targeting DNA methyltransferase 3A (DNMT3A) in HBV-related HCC tissues compared to adjacent noncancerous hepatic tissues. HBx-mediated miR-101 down-regulation and DNMT3A up-regulation supported the enhanced DNA methylation of several tumor-suppressor genes in $\mathrm{HBx}$-expressing cells. The study demonstrated that the deregulation of miR-101 expression by HBx probably provided a potential miRNA-based targeted approach for treating HBV-related HCC [40]. It is knowned that HBx play a critical role in the molecular pathogenesis of HBV-related HCC. Research found that HBx could suppresse p53-mediated activation of miR-148a. Expression of miR-148a was downregulated and negatively correlated with HPIP, a crucial regulator of cancer cell growth, which was upregulated in patients with cancer. Moreover, miR-148a reduced the growth, epithelial-to-mesenchymal transition, invasion, and metastasis of HBx-expressing hepatocarcinoma cells by inhibiting the HPIP-mediated mTOR signalings. To some certain extent, MiR-148a activation or HPIP inhibition may be a potential strategy for liver cancer treatment [41].

It has been reported that miR-205 can inhibit tumor Growth in vitro, and miR-205 expression level was inversely correlated with $\mathrm{HBx}$ [42]. HBx can induce miR-205 promoter to inhibit its expression, leading to the development of liver cancer. Besides, $\mathrm{HBx}$ can enhance expression of hepatoma cells miR-16 family in vitro, thereby promote the proliferation of hepatoma cells [43]. Therefore, HBx plays an important role in the development of HBV-related HCC.

\section{Host Cell MiRNA Regulate Transcription of HBV}

Accumulating evidence suggests that host-encoded miRNAs affect the replication and transcription of HBV. After liver cells infected with HBV, the expression of host cell miRNA can be changed. On the one hand, miRNA can promote transcription of $\mathrm{HBV}$ and induce the transformation of host cell to tumor cells. On the other hand, miRNA can inhibit the packaging and replication of HBV.

\subsection{Host Cell MiRNA Regulate HBV Transcription}

The HBV transcription is promoted mainly through two enhancers (enhancers I and II) and promoters of four region encoded. HBV enhancers promote transcription through the combination of STAT3 and HNF1/4 [44]. The C/EBP (CCAAT-binding protein) regulate $\mathrm{HBV}$ transcription positively by activating $\mathrm{HBV}$ enhancers or combination with the promoter region of C and S [45] [46]. MiRNA-155 inhibit HBV transcription 
by regulating C/EBP- $\beta$ negatively [47]. MiRNA-1 enhances Hepatitis B core Antigen (HBcAg) transcription by activating FXRA (transcription factor) [48]. Compared with male primary liver cancer patients, the expression of miRNA-18a in the female liver tissue is significantly upregulated. The experiment has proved that, miR-18a could regulate $\mathrm{HBV}$ transcription positively and promote the proliferation of liver cancer cells, through a combination of 3'untranslated region of the mRNA and expression of estrogen receptors down regulated [49].

However, compared with HepG2 cells, the report suggest that up-regulation of miR-199a-3p and miR-210 in HepG2 2.2.15 cells down-regulate HBV replication and maintenance of a suitable level of virion production in persistent infection by targeting crucial HBV genes. The results indicate that MiR-199a-3p and miR-210 target the HBV $S$ protein coding region and pre-S1 region, respectively [49]. MiR-501 can partially promote HBV replication by targeting HBXIP. So, knockdown of miR-501 can put up a new therapeutic way for suppressing HBV replication [51].

In addition, miR-7, miR-196b, miR-433, miR-511 can negatively regulate polymerase encoded HBV DNA gene and HBsAg gene. miR-205 negatively regulates transcription of $\mathrm{X}$ Zone gene and miR-345 negatively regulates transcription of target gene fragment pre-C [52]. It has been reported that serum miR-122 levels were significantly associated with HBsAg, and miR-122 can serve as an important indicator of viral transcription [53]. miR-581 can upregulate HBsAg expression by targeting Dicer and EDEM1 during hepatocarcinogenesis. Down regulation of miR-581 during hepatocarcinogenesis may result in reduction in HBsAg expression and impede HCC development [54].

\subsection{MicroRNA Regulate HBV Replication}

MiRNA can not only regulate HBV transcription, but also has important implications in HBV replication. The increasing researches on miRNA of HBV infection and related diseases is miR-122, it shows high expression in normal liver, and participates in lipid metabolism in the liver, differentiation and malignant transformation [55]. Overexpression of miR-122 can inhibit the replication of HBV and normal expression of miR122 can down-regulate hemachrome oxygenase-1 (HO-1) expression. The major role acted by $\mathrm{HO}-1$ in the $\mathrm{HBV}$ is reducing the stability of $\mathrm{HBV}$ core protein and reducing HBV cccDNA level [56]. Thus, miR-122 can inhibit HBV replication and make contributing to viral packaging [56]. Whereas, some reports implied that miR 122 expression was significantly downregulated in patients with chronic HBV infection, and Cyclin G1, as miR-122 target gene in patients with chronic infection in vivo, was highly expressed. Therefore, miR-122 can negatively regulate Cyclin G1 expression, and inhibit HBV replication [57] (Table 1). Overexpression of miR-29c effectively suppressed HBV DNA replication as well as inhibited cell proliferation and induced apoptosis by targeting TNFAIP3 (tumor necrosis factor alpha-induced protein 3) in the development and progression of HCC [58].

DNA methylation takes a great part in host gene silencing and suppressing $\mathrm{HBV}$ cccDNA transcription [44]. Several results reveal that compared with adjacentnon- 
Table 1. The aberrantly expressed miRNAs and potential biomarker in HBV-related disease.

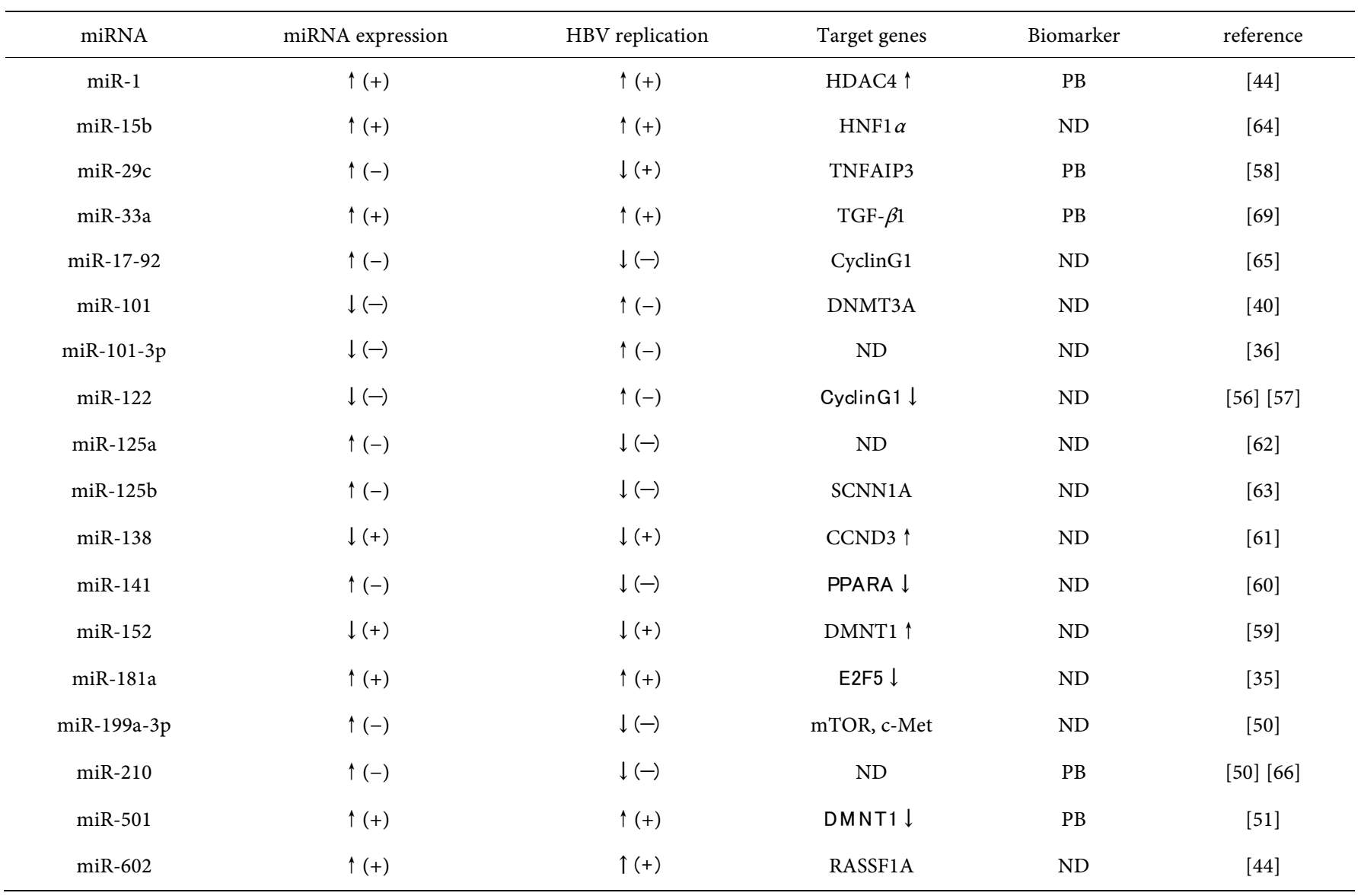

Abbreviations: “^ ”, upregulated; “ $\downarrow$ ”, downregulated; “+”, promotion; “-”, inhibition; “PB”, potential biomarker; “ND”, not determined.

cancerous hepatic tissues, the expression of miRNA-152 was down-regulated in HBVrelated HCC tissues. That is to say, the expression of miRNA-152 was inversely correlated to DNA methyltransferase 1 (DNMT1) expression in HBV-related HCCs. Findings show that miR-152 is frequently down-regulated and regulates DNMT1 in HBVrelated HCC, which support a tumorsuppressive role of miR-152 in the epigenetic aberration of HBV-related HCC. Expression of miR-152 was down-regulated and HBV replication was inhibited by targeting crucial HBV genes [59].

In addition, miRNAs can regulate HBV replication and keep the maintenance of a suitable level of virion production in persistent infection through modulate the HBVrelated factors or other associated molecules. Report shows that miR-141 can significantly suppress HBV expression and replication, and the results indicate that peroxisome proliferator-activated receptor alpha (PPARA) is the target of hsa-miR-141 during this process [60]. MiR-181a can negatively regulate E2F5, which is transcription factor, and promote HBV replication [34]. Research proved that miR-138 was downregulated in $77.8 \%$ of HCC tissues compared with adjacent non-tumor tissues. The downregulation of MiR-138 expression induced upregulation of CCND3 (cyclin D3) expression, and then, the cell cycle was stagnated [61]. MiR-1 can promote HBV repli- 
cation by activateing Farnesoid X receptor (farnesoid X receptor $\alpha$, FXRA) and downregulate the HDAC4 (histone deacetylase 4) [44]. miR-125a binds the viral transcript encoding the surface antigen and interferes with its expression, thus, it can inhibite HBV replication [62]. Expriments found that expression of miR-125b supressed HBV DNA intermediates and secretion of HBsAg and HBeAg. MiR-125b also inhibited the mRNA and protein levels of its potential target gene SCNN1A (sodium channel, nonvoltage-gated 1 alpha). Dual luciferase reporter system showed that SCNN1A was one of the targets of miR-125b [63]. Research found that miR-15b was able to promote $\mathrm{HBV}$ replication by augmenting HBV Enhancer I activity via direct targeting HNF1 $\alpha$, on the contrary, $\mathrm{HBV}$ replication, antigens expression and particularly the $\mathrm{HBx}$ protein repressed the expression of $\mathrm{miR}-15 \mathrm{~b}$. The reciprocal regulation between miR-15b and HBV can control the level of HBV replication [64].

Finally, the oncogenes can regulate the HBV replication with miRNA. The overexpression of miRNA-17-92 can suppress HBV replication in hepatoma cells (Table 1) [65]. Host cell affects HBV replication through cytokines or genes HBV-related, and the mechanisms can provide new approaches for the treatment of HBV related disease.

\section{Chronic HBV Infection Affects Host MiRNA}

Chronic HBV infection altered hepatocytes and whole body dynamic balance, and fially cause the occurrence of liver cirrhosis and HCC. Chronic infection plays a great part role in miRNA of host serum and liver cells.

\subsection{Influence of HBV on the MicroRNA Expression in Host Serum}

The template is designed so that author affiliations are not repeated each time for multiple authors of the same affiliation. Please keep your affiliations as succinct as possible (for example, do NOT post your job titles, positions, academic degrees, zip codes, names of building/street/district/province/state, etc.). This template was designed for two affiliations. Due to the influence of HBV having on miRNA of host serum is specific, specific expression of miRNA plays an important role in diagnosis of HBV-related diseases. To confirm relationship between hypoxia and miR-210 levels, the concanavalin A murine hepatitis model and inflammation were used. The results show that the miR-210 elevation might be related to the decreases in HepG2.2.15 cell dehydrogenase activity and HBV replication under hypoxic conditions. The liver inflammation can lead to liver hypoxia and cause liver and serum miR-210 levels elevation. So, the serum miR-210 level might be a potential biomarker for severity of hepatitis increases in liver hypoxia and miR-210 [66].

In addition, experiments show that the level of serum miR-17-5p is associated with development of HCC, the expression of serum miR-17-5p was significantly downregulated in the post-operative group and up-regulated in the relapsed group. Hence, serum miR-17-5p may be a ideal biomarker for the prognostic prediction of HCC patients [67].

A panel detected expression of miR-150 using a real-time quantitative RT-PCR in 
350 serum samples (120 samples from controls, 110 samples from $\mathrm{CHB}$ patients and 120 samples from HCC patients). The results showed that serum miR-150 levels were strikingly reduced in HCC patients, compared with healthy controls and CHB patients. Serum miR-150 levels were increased after surgical operation and decreased after tumor recurrence. HCC patients with lower serum miR-150 had a significantly shortened overall survival. Serum miR-150 can be a non-invasive biomarker for the diagnosis and prognosis of HCC patients [68].

In the serum of patients with liver cancer and cirrhosis, the miR-885-5p expression has upregulation and has a higher specificity [32] [33]. The expression levels of miR125b-5p were up regulated in CHB, HBV-positive cirrhosis and HBV-positive HCC, HBV-positive HCC, respectively. Whereas, the expression levels of miR-223-3p were down regulated in same comparisons. Thus, miR-125b-5p and miR-223-3p can be used as a potential marker for the detection of liver disease [33].

\subsection{HBV Influence on the MicroRNA Expression in the Host Tissues}

A panel showed that miR-33a expression levels in liver tissue of CHB patients remarkably increased with a fibrosis progression manner in the human liver. In addition, serum miR-33a levels associated positively with progressing process of hepatic fibrosis. miR-33a was in particular increased in hepatic stellate cells (HSC) than other liver fibrosis-associated cells. Stimulation of HSCs with transforming growth factor- $\beta 1$ (TGF$\beta 1$ ) resulted in significant increase of miR-33a, which reversely enhanced the activation role of TGF- $\beta 1$ in LX- 2 cells. miR-33a may be a novel therapeutic target in liver fibrosis [69].

Compared with the expression of liver cancer miRNA in patients has remarkable discrimination with that of non-malignant tumour patients. The expression of miRNAs (miR-21, miR-22, miR-224, miR-34a, miR-221/222, miR-106a, miR-203) in liver cancer obviously upregulate. However, the expression of miRNAs (miR-34c, miR-139, miR422b, miR-145 and miR-199b) obviously downregulate [37] [70]-[74]. Moreover, miR602 expression in chronic HBV infection and liver cells significantly upregulated. The expression level of miR-602 was gradually rising with the deterioration of the liver cancer. MiR-602 leads to the occurrence and development of a series of liver disease through inhibiting RASSF1A (Ras-association domain family 1A gene) expression and regulating hepatocyte growth [44].

\section{Conclusions}

During the last decade, miRNAs have emerged as critical regulators of HBV replication and pathogenesis. There have been extensive researches demonstrated the relationship between miRNAs' aberrant expression and HBV-related diseases (Table 1). Several miRNAs can promote transcription of $\mathrm{HBV}$ and induce the transformation from host cells to tumor cells, for example, miR-1 and miR-18a could regulate HBV transcription positively and promote the proliferation of liver cancer cells. However, some microRNAs can inhibit packaging and replication of HBV, for example, miR-122 expression 
was significantly downregulated in patients with chronic HBV infection and can inhibit packaging and replication of HBV. On the contrary, HBV infection can regulate the expression of microRNAs in the host serum, for example, the expression of serum miR-17-5p was significantly down-regulated in the post-operative group and up-regulated in the relapsed group.

MiRNA acts an essential role in replication of HBV and pathogenesis of HBV-related diseases. The expression profile of microRNAs in liver cells can be changed under HBV infection. Just as Table 1 showed that, miR-1, miR-29c, miR-33a, miR-210 and miR501 are being the potential biomarkers for disease diagnosis.

\section{References}

[1] Jin, W.-B., Wu, F.-L., Kong, D., et al. (2007) HBV-Encoded MicroRNA Candidate and Its Target Computational. Biology and Chemistry, 31, 124-126.

[2] Galliano, D. and Pellicer, A. (2014) MicroRNA and Implantation. Fertility and Sterility, 101, 1531-1544. http://dx.doi.org/10.1016/j.fertnstert.2014.04.023

[3] Vasudevan, S. (2012).Functional Validation of MicroRNA-Target RNA Interactions. Methods, 58, 126-134. http://dx.doi.org/10.1016/j.ymeth.2012.08.002

[4] Fire, A., Xu, S., Montgomery, M.K., et al. (1998) Potent and Specific Genetic Interference by Double Stranded RNA in Caenorhabditis elegans. Nature, 391, 806-811. http://dx.doi.org/10.1038/35888

[5] Lee, R.C., Feinbaum, R.L. and Ambros, V. (1993) The C. elegans Heterochronic Gene Lin-4 Encodes Small RNAs with Antisense Complementarity to Lin-14. Cell, 75, 843-854. http://dx.doi.org/10.1016/0092-8674(93)90529-Y

[6] Kim, V.N. (2004) MicroRNA Precursors in Motion: Exportin-5 Mediates Their Nuclear Export. Trends Cell Biol., 14, 156-159. http://dx.doi.org/10.1016/j.tcb.2004.02.006

[7] Zeng, Y. and Cullen, B.R. (2004) Structural Requirements for Pre-MicroRNA Binding and Nuclear Export by Exportin 5. Nucl. Acids Res., 32, 4776-4785. http://dx.doi.org/10.1093/nar/gkh824

[8] Bartel, D.P. (2004) MicroRNAs, Genomics, Biogenesis, Mechanism, and Function. Cell, 116, 281-297. http://dx.doi.org/10.1016/S0092-8674(04)00045-5

[9] Hunter, C. and Poethig, S.R. (2003) Missing Links, miRNAs and Plant Development. Curr. Opin. Genet. Dev., 13, 372-378. http://dx.doi.org/10.1016/S0959-437X(03)00081-9

[10] Rajewskya, N. and Soccib,c, N.D. (2004) Computational Identification of MicroRNA Targets. Developmental Biology, 267, 529-535. http://dx.doi.org/10.1016/j.ydbio.2003.12.003

[11] Griffiths-Jones, S. (2004) The MicroRNA Registry. Nucl. Acids Res., 32, D109-D111. http://dx.doi.org/10.1093/nar/gkh023

[12] Ambros, V. (2003) MicroRNA Pathways in Flies and Worms: Growth, Death, Fat, Stress, and Timing. Cell, 113, 673-676. http://dx.doi.org/10.1016/S0092-8674(03)00428-8

[13] Aravin, A.A., Lagos-Quintana, M. and Yalcin, A. (2003) The Small RNA Profile during Drosophila melanogaster Development. Dev. Cell, 5, 337-350. http://dx.doi.org/10.1016/S1534-5807(03)00228-4

[14] Lagos-Quintana, M., Rauhut, R., Lendeckel, W. and Tuschl, T. (2001) Identification of Novel Genes Coding for Small Expressed RNAs. Science, 294, 853-858. http://dx.doi.org/10.1126/science.1064921

[15] Lai, E.C., Tomancak, P., et al. (2003) Computational Identification of Drosophila Micro- 
RNA Genes. Genome Biol., 4, R42. http://dx.doi.org/10.1186/gb-2003-4-7-r42

[16] Lau, N.C., Lim, L.P., Weinstein, E.G. and Bartel, D.P. (2001) An Abundant Class of Tiny RNAs with Probable Regulatory Roles in Caenorhabditis elegans. Science, 294, 858-862. http://dx.doi.org/10.1126/science.1065062

[17] Lee, R.C. and Ambros, V. (2001) An Extensive Class of Small RNAs in Caenorhabditis elegans. Science, 294, 862-864. http://dx.doi.org/10.1126/science.1065329

[18] Lim, L.P., Glasner, M.E., Yekta, S., Burge, C.B. and Bartel, D.P. (2003a) Vertebrate MicroRNA Genes. Science, 299, 1540. http://dx.doi.org/10.1126/science.1080372

[19] Lim, L.P., Lau, N.C., Weinstein, E.G., Abdelhakim, A., Yekta, S., Rhoades, M.W., Burge, C.B. and Bartel, D.P. (2003b) The MicroRNAs of Caenorhabditis elegans. Genes Dev., 17, 991-1008. http://dx.doi.org/10.1101/gad.1074403

[20] Ørom, U.A. and Lund, A.H. (2010) Experimental Identification of MicroRNA Targets. Gene, 451, 1-5. http://dx.doi.org/10.1101/gad.1074403

[21] Griffiths-Jones, S., Saini, H.K., Dongen, S.V. and Enright, A.J. (2008) miRBase: Tools for MicroRNA Genomics. Nucleic Acids Res., 36, D154-D158.

http://dx.doi.org/10.1093/nar/gkm952

[22] Kotlabova, K., Doucha, J. and Hromadnikova, I. (2011) Placental-Specific MicroRNA in Maternal Circulation-Identification of Appropriate Pregnancy-Associated MicroRNAs with Diagnostic Potential. J Reprod Immunol, 89, 185-191. http://dx.doi.org/10.1016/j.jri.2011.02.006

[23] He, L., He, X., Lowe, S.W. and Hannon, G.J. (2007) MicroRNAs Join the p53 Network-Another Piece in the Tumour-Suppression Puzzle. Nat. Rev. Cancer, 7, 819-822. tp://dx.doi.org/10.1016/j.jri.2011.02.006

[24] Parker, R. and Sheth, U. (2007) P Bodies and the Control of mRNA Translation and Degradation. Mol. Cell, 25, 635-646. http://dx.doi.org/10.1016/j.molcel.2007.02.011

[25] Pillai, R.S., Bhattacharyya, S.N. and Filipowicz, W. (2007) Repression of Protein Synthesis by miRNAs: How Many Mechanisms? Trends Cell Biol., 17, 118-126. http://dx.doi.org/10.1016/j.tcb.2006.12.007

[26] Carthew, R.W. and Sontheimer, E.J. (2009) Origins and Mechanisms of miRNAs and siRNAs. Cell, 136, 642-655. http://dx.doi.org/10.1016/j.cell.2009.01.035

[27] Lee, Y., Jeon, K., Lee, J.T., Kim, S. and Kim, V.N. (2002) MicroRNA Maturation, Stepwise processing and subcellular localization. $E M B O$ J., 21, 4663-4670. http://dx.doi.org/10.1093/emboj/cdf476

[28] Jopling, C.L., Yi, M., Lancaster, A.M., Lemon, S.M. and Sarnow, P. (2005) Modulation of Hepatitis C Virus RNA Abundance by a Liver-Specific MicroRNA. Science, 309, 1577 1581. http://dx.doi.org/10.1126/science.1113329

[29] Xu, L., Qi, X.L., Duan, S.L., et al. (2014) MicroRNA: Potential Biomarkers for Disease Diagnosis. Bio-Medical Materials and Engineering, 24, 39157-3925.

[30] Cuestas, M.L., Mathet, V.L., Oubiña, J.R. and Sosnik, A. (2010) Drug Delivery Systems and Liver Targeting for Improved Pharmacotherapy of the Hepatitis B Virus (HBV) Infection. Pharm Res, 27, 1184-1202. http://dx.doi.org/10.1007/s11095-010-0112-Z

[31] Jiang, S.-Z., Zheng, J.-J., et al. (2012) Hepatitis B Virus S Promoter Deletionin Hepatocellular Carcinoma. Infection International (Electronic Edition), 1, 14-23.

[32] Gui, J., Tian, Y., Wen, X., et al. (2011) Serum MicroRNA Characterization Identifies miR-885-5p as a Potential Marker for Detecting Liver Pathologies. Clin Sci: Lond, 120, 183193. http://dx.doi.org/10.1042/CS20100297 
[33] Giray, B.G., Emekdas, G., Tezcan, S., et al. (2014) Profiles of Serum MicroRNAs; miR125b-5p and miR223-3p Serve as Novel Biomarkers for HBV-Positive Hepatocellular Carcinoma. Mol Biol Rep, 41, 4513-4519. http://dx.doi.org/10.1007/s11033-014-3322-3

[34] Li, T., Yin, J., Yuan, L., et al. (2014) Downregulation of MicroRNA-139 Is Associated with Hepatocellular Carcinoma Risk and Short-Term Survival. Oncol Rep, 31, 1699-1706. http://dx.doi.org/10.3892/or.2014.3032

[35] Zou, C., Li, Y., Cao, Y., et al. (2014) Up-Regulated MicroRNA-181a Induces Carcinogenesis in Hepatitis B Virus-Related Hepatocellular Carcinoma by Targeting E2F5. BMC Cancer, 14, 97. http://dx.doi.org/10.1186/1471-2407-14-97

[36] Sheng, Y.R., Ding, S.J., et al. (2014) Functional Analysis of miR-101-3p and Rap1b Involved in Hepatitis B Virus-Related Hepatocellular Carcinoma Pathogenesis. Biochemistry and Cell Biology, 92, 152-162. http://dx.doi.org/10.1139/bcb-2013-0128

[37] Ganem, D., Schneider, R.J. (2001) The Molecular Biology of the Hepatitis B Viruses. In: Knipe, D.M., et al., Eds., Fields Virology, 4th Edition, Lippincott Williams \& Wilkins, Philadelphia, 2923-2970.

[38] Kremsdorf, D., Soussan, P., Paterlini-Brechot, P. and Brechot, C. (2006) Hepatitis B Virus-Re- lated Hepatocellular Carcinoma: Paradigms for Viral-Related Human Carcinogenesis. Oncogene, 25, 3823-3833.

[39] Geng, X., Huang, C.H., Qin, Y., et al. (2012) Hepatitis B Virus X Protein Targets Bcl-2 Proteins to Increase Intracellular Calcium, Required for Virus Replication and Cell Death Induction. PNAS, 109, 18471-18476. http://dx.doi.org/10.1073/pnas.1204668109

[40] Wei, X.F., Xiang, T.X., Ren, G.S., et al. (2013) miR-101 Is Down-Regulated by the Hepatitis $B$ Virus $x$ Protein and Induces Aberrant DNA Methylation by Targeting DNA Methyltransferase 3A. Cellular Signalling, 25, 439-446. http://dx.doi.org/10.1016/j.cellsig.2012.10.013

[41] Xu, X.J., Fan, Z.Y., Kang, L., Han, J.Q., et al. (2013) Hepatitis B Virus X Protein Represses miRNA-148a to Enhance Tumorigenesis. Clin Invest, 123, 630-645. http://dx.doi.org/10.1172/jci64265

[42] Zhang, T., Zhang, J., Cui, M., et al. (2013) Hepatitis B Virus X Protein Inhibits Tumor Suppressor miR-205 through Inducing Hypermethylation of miR-205 Promoter to Enhance Carcinogenesis. Neoplasia, 15, 982-1991. http://dx.doi.org/10.1593/neo.131362

[43] Wu, G., Yu, F., Xiao, Z., et al. (2011) Hepatitis B Virus X Protein Downregulates Expression of the miR-16 Family in Malignant Hepatocytes In Vitro. Br J Cancer, 105, 1146-1153. http://dx.doi.org/10.1038/bjc.2011.190

[44] Liu, W.H., Yeh, S.H. and Chen, P.J. (2011) Role of MicroRNAs in Hepatitis B Virus Replication and Pathogenesis. Biochim Biophys Acta, 1809, 678-685.

http://dx.doi.org/10.1016/j.bbagrm.2011.04.008

[45] Lopez-Cabrera, M., Letovsky, J., Hu, K.Q., et al. (1990) Multiple Liverspecific Factors Bind to the Hepatitis B Virus Core/Pregenomic Promoter: Transactivation and Repression by CCAAT/Enhancer Binding Protein. Proc Natl Acad Sci USA, 87, 5069-5073. http://dx.doi.org/10.1073/pnas.87.13.5069

[46] Bock, C.T., Kubicka, S., Manns, M.P., et al. (1999) Two Control Elements in the Hepatitis B Virus S-Promoter Are Important for Full Promoter Activity Mediated by CCAAT-Binding Factor. Hepatology, 29, 1236-124. http://dx.doi.org/10.1002/hep.510290426

[47] Sarkar, N., Panigrahi, R., Pal, A., Biswas, A., Singh, S.P., et al. (2015) Expression of MicroRNA-155 Correlates Positively with the Expression of Toll-Like Receptor 7 and Modulates Hepatitis B Virus via C/EBP- $\beta$ in Hepatocytes. Journal of Viral Hepatitis, 22, 817-827. 
http://dx.doi.org/10.1111/jvh.12390

[48] Wang, B., Majumder, S., Nuovo, G., et al. (2009) Role of MicroRNA-155 at Early Stages of Hepatocarcinogenesis Induced by Choline-Deficient and Amino Acid-Defined Diet in C57BL/6 Mice. Hepatology, 50, 1152-1161. http://dx.doi.org/10.1002/hep.23100

[49] Liu, W.H., Yeh, S.H., Lu, C.C., et al. (2009) MicroRNA-18a preventsestrogen Receptor-a Expression, Promoting Proliferation of Hepatocellular Carcinoma Cells. Gastroenterology, 136, 683-693. http://dx.doi.org/10.1053/j.gastro.2008.10.029

[50] Zhang, G.-L., Li, Y.-X., Zheng, S.-Q., Liu, M., Li, X. and Tang, H. (2010) Suppression of Hepatitis B Virus Replication by MicroRNA-199a-3p and MicroRNA-210. Antiviral Research, 88, 169-175. http://dx.doi.org/10.1016/j.antiviral.2010.08.008

[51] Jin, J., Tang, S., Xia, L., et al. (2013) MicroRNA-501 Promotes HBV Replication by Targeting HBXIP. Biochem Biophys Res Commun, 430, 1228-1233.

http://dx.doi.org/10.1016/j.bbrc.2012.12.071

[52] Wu, F.L., Jin, W.B., Li, J.H., et al. (2011) Targets for Human Encoded MicroRNAs in HBV Genes. Virus Genes, 42, 157-161. http://dx.doi.org/10.1007/s11262-010-0555-7

[53] Waidmann, O., Bihrer, V., Pleli, T., et al. (2012) Serum MicroRNA-122 Levels in Different Groups of Patients with Chronic Hepatitis B Virus Infection. J Viral Hepat, 19, e58-e65. http://dx.doi.org/10.1111/j.1365-2893.2011.01536.x

[54] Wang, Y.-Q., Ren, Y.-F., Song, Y.-J., et al. (2014) MicroRNA-581 Promotes Hepatitis B Virus Surface Antigen Expression by Targeting Dicer and EDEM1. Carcinogenesis, 35, 21272133. http://dx.doi.org/10.1093/carcin/bgu128

[55] Thirion, M., Ochiya, T. (2013) Roles of MicroRNAs in the Hepatitis B Virus Infection and Related Diseases. Viruses, 5, 2690-2703. http://dx.doi.org/10.3390/v5112690

[56] Qiu, L., Fan, H., Jin, W., et al. (2010) miR-122-Induced Down-Regulation of HO-1 Negatively Affects miR-122-Mediated Suppression of HBV. Biochem Biophys Res Commun, 398, 771-777. http://dx.doi.org/10.1016/j.bbrc.2010.07.021

[57] Wang, S., Qiu, L., Yan, X., et al. (2012) Loss of MicroRNA-122 Expression in Patients with Hepatitis B Enhances Hepatitis B Virus Replication through Cyclin G1-Modulated P53 Activity. Hepatology, 55, 730-741. http://dx.doi.org/10.1002/hep.24809

[58] Wang, C.-M., Wang, Y., et al. (2011) miR-29c Targets TNFAIP3, Inhibits Cell Proliferation and Induces Apoptosis in Hepatitis B Virus-Related Hepatocellular Carcinoma. Biochemical and Biophysical Research Communications, 411, 586-592. http://dx.doi.org/10.1016/j.bbrc.2011.06.191

[59] Huang, J., Wang, Y., Guo, Y., et al. (2010) Down-Regulated MicroRNA-152 Induces Aberrant DNA Methylation in Hepatitis B Virus-Related Hepatocellular Carcinoma by Targeting DNA Methyltransferase 1. Hepatology, 52, 60-70. http://dx.doi.org/10.1002/hep.23660

[60] Hu, W., Wang, X., Ding, X., et al. (2012) MicroRNA-141 Represses HBV Replication by Targeting PPARA. PLoS One, 7, e34165. http://dx.doi.org/10.1371/journal.pone.0034165

[61] Wang, W., Zhao, L.J., Tan, Y.X., et al. (2012) MiR-138 Induces Cell Cycle Arrest by Targeting Cyclin D3 in Hepatocellular Carcinoma. Carcinogenesis, 33, 1113-1120. http://dx.doi.org/10.1093/carcin/bgs113

[62] Moscaa, N., Castielloa, F., et al. (2014) Functional Interplay between Hepatitis B Virus X Protein and Human miR-125a in HBV Infection. Biochemical and Biophysical Research Communications, 449, 141-145. http://dx.doi.org/10.1016/j.bbrc.2014.05.009

[63] Zhang, Z.z., Chen, J., et al. (2014) miR-125b Inhibits Hepatitis B Virus Expression In Vitro through Targeting of the SCNN1A Gene. Arch Virol, 59, 3335-3343.

ttp://dx.doi.org/10.1007/s00705-014-2208-y 
[64] Dai, X., Zhang, W., Zhang, H., Sun, S., Yu, H., et al. (2014) Modulation of HBV Replication by MicroRNA-15b through Targeting Hepatocyte Nuclear Factor 1a. Nucleic Acids Research, 42, 6578-6590. http://dx.doi.org/10.1093/nar/gku260

[65] Jung, Y.J., Kim, J.W., Park, S.J., et al. (2013) c-Myc-Mediated Overexpression of miR-17-92 Suppresses Replication of Hepatitis B Virus in Human Hepatoma Cells. J Med Virol, 85, 969-978. http://dx.doi.org/10.1002/jmv.23534

[66] Song, G., Jia, H., Xu, H., et al. (2014) Studying the Association of MicroRNA-210 Level with Chronic Hepatitis B Progression. J Viral Hepat, 21, 272-280.

http://dx.doi.org/10.1111/jvh.12138

[67] Zheng, J., Dong, P., Gao, S., et al. (2013) High Expression of Serum miR-17-5p Associated with Poor Prognosis in Patients with Hepatocellular Carcinoma. Hepatogastroenterology, 60, 549-552.

[68] Yu, F.J., Lu, Z.Q., Chen, B.C., Dong, P.H. and Zheng, J.J. (2015) MicroRNA-150: A Promising Novel Biomarker for Hepatitis B Virus-Related Hepatocellular Carcinoma. Diagnostic Pathology, 10, 1-9. http://dx.doi.org/10.1186/s13000-015-0369-y

[69] Huang, C.-F., Sun, C.-C., Zhao, F., et al. (2015) miR-33a Levels in Hepatic and Serum after Chronic HBV-Induced Fibrosis. Journal of Gastroenterology, 50, 480-490. http://dx.doi.org/10.1007/s00535-014-0986-3

[70] Chen, X.M. (2009) MicroRNA Signatures in Liver Diseases. World J Gastroenterol, 15, 1665-1672. http://dx.doi.org/10.3748/wjg.15.1665

[71] Shi, C.L. and Xu, X.D. (2013) MicroRNA-22 Is Down-Regulated in Hepatitis B Virus-Related Hepatocellular Carcinoma. Biomedicine and Pharmacotherapy, 67, 375-380. http://dx.doi.org/10.1016/j.biopha.2013.03.002

[72] Wang, Y., Wang, C.-M., et al. (2015) MicroRNA-34c Targets TGFB-Induced Factor Homeobox 2, Represses Cell Proliferation and Induces Apoptosis in Hepatitis B Virus-Related Hepatocellular Carcinoma. Oncology Letters, 10, 3095-3102.

[73] Shi, C.L. and Xu, X.D. (2013) MicroRNA-22 Is Down-Regulated in Hepatitis B Virus-Related Hepatocellular Carcinoma. Biomedicine and Pharmacotherapy, 67, 375-380. http://dx.doi.org/10.1016/j.biopha.2013.03.002

[74] Wang, Y., Wang, C.-M., et al. (2015) MicroRNA-34c Targets TGFB-Induced Factor Homeobox 2, Represses Cell Proliferation and Induces Apoptosis in Hepatitis B Virus-Related Hepatocellular Carcinoma. Oncology Letters, 10, 3095-3102. 
Submit or recommend next manuscript to SCIRP and we will provide best service for you:

Accepting pre-submission inquiries through Email, Facebook, LinkedIn, Twitter, etc.

A wide selection of journals (inclusive of 9 subjects, more than 200 journals)

Providing 24-hour high-quality service

User-friendly online submission system

Fair and swift peer-review system

Efficient typesetting and proofreading procedure

Display of the result of downloads and visits, as well as the number of cited articles

Maximum dissemination of your research work

Submit your manuscript at: http://papersubmission.scirp.org/

Or contact jbise@scirp.org 